\title{
Article
}

\section{Do Deposit Insurance Systems Promote Banking Stability?}

\author{
Nafis Alam ${ }^{1}$ (D), Ganesh Sivarajah ${ }^{2}$ and Muhammad Ishaq Bhatti ${ }^{3, *(D)}$ \\ 1 School of Accounting and Finance, Asia Pacific University of Technology and Innovation (APU), \\ Kuala Lumpur 51200, Malaysia; nafis.alam@apu.edu.my \\ 2 Gibraltar BSN Life Berhad, Kuala Lumpur 59200, Malaysia; Gan.sivarajah@gmail.com \\ 3 Department of Economics, Finance and Marketing, La Trobe Business School, La Trobe University, \\ Melbourne, VIC 3086, Australia \\ * Correspondence: i.bhatti@latrobe.edu.au
}

check for updates

Citation: Alam, Nafis, Ganesh Sivarajah, and Muhammad Ishaq Bhatti. 2021. Do Deposit Insurance Systems Promote Banking Stability? International Journal of Financial Studies 9: 52. https:// doi.org/10.3390/ijfs9030052

Academic Editors: Sabri Boubaker, Konstantinos Baltas, Thanh Ngo and Ronald A. Ratti

Received: 13 July 2021

Accepted: 16 September 2021

Published: 18 September 2021

Publisher's Note: MDPI stays neutral with regard to jurisdictional claims in published maps and institutional affiliations.

Copyright: (C) 2021 by the authors. Licensee MDPI, Basel, Switzerland. This article is an open access article distributed under the terms and conditions of the Creative Commons Attribution (CC BY) license (https:/ / creativecommons.org/licenses/by/ $4.0 /)$.

\begin{abstract}
During the global financial crisis (GFC), regulators and policymakers turned to deposit insurers, along with monetary and fiscal measures, to help restore market confidence and promote financial stability. These events have focused attention on the role of deposit insurers and their role in the banking system. Recent literature reveals that during the GFC, deposit insurance maintained banking stability and successfully prevented customers doing 'runs' on the banks. The objective of this paper is to examine the deposit insurance system's coverage limits and the impact on banking stability, in the context of a jurisdiction's economic and institutional environment. Our model examines 61 jurisdictions in Asia and Europe with explicit deposit insurance systems, covering the pre- and post-GFC period between 2004 and 2014. We also examine subsets to investigate the effects of the region by comparing Asia and Europe, as well as a subset using the date of establishment of the deposit insurance system to understand if maturity matters. The results indicate that deposit insurance systems, and specifically deposit insurance coverage levels, have both positive and negative effects on banking stability. We find significant associations with certain economic and institutional factors; however, there are differences between the models we ran. These can be ascribed to regional factors and the date of when a deposit insurance system was established.
\end{abstract}

Keywords: deposit insurance; banking; financial stability; financial crisis

\section{Introduction}

Recently, Kozińska (2021) highlighted the importance of deposit insurance which grew from obscurity following the 2008/9 global financial crisis (GFC). During this period, retail depositors in Greece, Iceland, Cyprus, and the United Kingdom discovered that their banks were in distress and facing huge governance and financial discrepancy issues. The potential failure of large financial institutions was a threat to the whole economic system, and governments including regulators, had to take extraordinary measures to restore financial stability during the GFC (Al Rahahleh and Bhatti 2017; Baghdadi et al. 2018; Azmat et al. 2020). One extraordinary measure taken by policymakers was providing temporary unlimited coverage or extending coverage levels to boost people's confidence in the finance system (Anginer et al. 2014; Nguyen et al. 2016). The call for better deposit insurance gained more prominence during the recent COVID-19 pandemic as depositors now demand deposit insurers in meeting payout obligations in case banking systems fail to cope with prevailing economic conditions. Sabourin (2020) noted that flexibility to access or call upon a wide and varied range of stabilization tools such as deposit insurance is very important to quickly meet the challenges presented by fast changing circumstances. The argument for the importance of banking stability is premised on the role that banking systems play and the potential damage they can do if things go wrong. This argument is noted in a speech by the Governor of the Swedish National Bank (Ingves 2012):

The financial system basic functions are converting savings to investments, managing risks and mediating payments. Banks are dependent on confidence, are highly leveraged 
and are thus vulnerable. Problems in the financial sector are contagious. Precisely because we need the financial system so much, reducing the risk of financial crises must be an important priority. Financial crises cause great damage to society.

A core argument for banking stability is the toll it takes on a nation's economy and financial progress. After Sweden's banking crisis of the 1990s, the economy lost almost 20 per cent of GDP while unemployment rose to double digits and interest rates increased, burdening customers (Ingves 2012). On this link between a well-developed and open banking sector and economic growth, some studies (Jokipii and Monnin 2013; Cerrone 2018) found that a healthy banking system was connected to financial and economic development. Barth et al. (2009) observed that the inherent fragility of banks has motivated countries to establish deposit insurance systems to assure depositors that their money is safe. They also emphasized that the credibility of the guarantee is contingent upon the belief that depositors have of the government honoring their promise. Such has been the importance of the deposit insurance that in November 2015 the European Commission proposed setting up a unified European deposit insurance scheme (EDIS) for bank deposits in the euro area (Wiedner 2020). In our view, this is the key element of deposit insurance in which depositors must believe that the deposit insurer can fulfil its promises and obligations, otherwise confidence in the finance system will disappear.

The benefits and costs of deposit insurance are debatable, but the fact that 146 jurisdictions now have deposit insurance systems (IADI 2021) in place reflects the importance of the debate. In terms of economic theory, Anginer et al. (2014) suggest that deposit insurance brings both benefits and costs to banking stability. Moreover, this relationship varies depending on economic conditions and according to the theory, during a strong economy, banks take on more risk to earn more profits knowing that they have the protection of deposit insurance. The potential moral hazard from deposit insurance has been debated by academics, some of whom contend that deposit insurance promotes banking instability. Conversely, others think that deposit insurance boosts depositor confidence, promotes banking stability, and reduces the potential of bank runs during economic crises (Anginer et al. 2014). Another key theoretical concept about the relationship between deposit insurance and banking stability is that deposit insurance represents an inexpensive way during good times to reduce the risks of bank runs by stabilizing the banking system. In effect, this means providing reassurance and confidence (Demirgüç-Kunt and Kane 2002). Authors further asserted that deposit insurance provides smaller banks with an opportunity to compete with larger institutions for deposits because it removes the risk of failure and losses by depositors. In contrast, removing the risk of failure means depositors cannot monitor what the banks are doing with their money, potentially leading to risky behavior by banks (see Rastogi et al. 2021). In another strand of literature, it has been noted that an efficient banking system not only brings stability to the financial system but also helps to develop a robust and well-functioning capital market (see Alam et al. 2018; Ngo and Le 2019; Lu et al. 2018; Nguyen et al. 2018).

This study aims to contribute to the literature on the effects of deposit insurance on banking stability in three main ways. Firstly, although seminal work on this topic has examined deposit insurance globally, analyses in a regional context are lacking (DemirgüçKunt and Detragiache 2002). This paper will examine deposits globally and then break down the study by looking at two regions, Europe and Asia. The decision to look at these two regions was driven by the differences in their state of economic progress, institutional development, and banking models. Secondly, we want to examine whether the maturity level of the deposit insurance scheme has an impact on banking stability using two sets of timeframes, 1961-1985 and 1987-2013. Thirdly, the study will cover 61 jurisdictions with explicit deposit insurance in Europe and Asia during the period 2004-2014, covering the pre-and post-phases of the GFC. This is tabulated in Appendix A. This time period provides data to compare crisis and non-crisis periods. This is especially true for Europe where there were 22 banking crises in our data set. 
The rest of this paper is organized as follows. In the following sections, a brief literature review on the contribution of the effects of deposit insurance on banking stability is presented. The data details and model for banking stability are discussed in Section 3. Section 4 deals with the results and the final section contain some concluding remarks.

\section{Literature Review}

One of the key policy challenges faced by deposit insurers is finding the right balance between the gains from preventing a crisis and maintaining financial stability versus the costs to control risk-taking by banks and their customers (Demirgüç-Kunt et al. 2008a). We noted that if deposit insurers had a precise method to measure the risk of individual banks and price the costs of insuring banks accurately, this would ensure that managing costs of insurance will be fairer since higher-risk banks pay more. However, in practice, this is challenging due to the complexity of measuring and capturing risks and applying a pricing mechanism to them (Flannery 1991).

Over the decades the deposit insurance systems have expanded from 12 in 1974 to 146 as of 2021 (IADI 2021). The growth of explicit deposit insurance can be explained by the strong support given by the International Monetary Fund (IMF) and the World Bank for deposit insurance systems as part of crisis management (Demirgüç-Kunt et al. 2008b). These policies are accepted by national governments since they believe that banks are vital to their economies but are susceptible to liquidity crises and insolvency (Garcia 1999). Papers published in the last decade show that governments are expanding financial safety nets after the GFC by providing more coverage, nationalizing banks, and covering non-deposit liabilities (Demirgüç-Kunt et al. 2014a). Much of this has been driven by policymakers assuming that deposit insurance gives the financial system stability.

After the GFC, deposit insurance systems delivered on their objective to prevent widespread bank runs and despite the large shocks to the finance system (Demirgüç-Kunt et al. 2014b), proved their ability to bolster it. A major testament to the effectiveness of the deposit insurance system is that the FDIC oversaw the failure of over 100 banks in the United States and depositors who continued to put their faith in the FDIC with the assumption that their deposits were protected (Evanoff and Kaufman 2011). Further empirical evidence from the European Union revealed that deposit insurance gave a lot of incentive to other creditors, who are not covered by the explicit guarantee, to monitor the banks and thus reduce moral hazard (Gropp and Vesala 2004). In the formative work by Diamond and Dybvig (1983), their modeling of an economy with a single bank found that government intervention through deposit insurance is benefited by preventing bank runs.

Deposit insurance also provides a level playing field for all banks by removing the advantage large systemic banks received through implicit government guarantees (Lé 2013). Demirgüç-Kunt et al. (2008b), in their research on deposit insurance, remark that a credible deposit insurance system can contribute to financial stability by reducing the likelihood of bank runs. Their analysis found that during a crisis, deposit insurance diminished bank risks and enhanced financial stability. In another strand of literature, supporters of the deposit insurance system argue that effective regulatory institutions and well-governed banks will mitigate the risk of moral hazard (Anginer et al. 2014). Furthermore, in the investigation on the role of the deposit insurance scheme on financial stability, DemirgüçKunt and Detragiache (2002) reported that explicit deposit insurance can be detrimental to bank stability especially if institutions are charged with oversight responsibilities are weak and the banking system is overly deregulated. In a similar context, Igwe and Toby (2021), while examining the relationship between deposit insurance and nonperforming loans ratio of the Nigeria banking system, found that insured deposits and risk-based premium have a negative relationship with the level of bank distress, stressing that a deposit insurance scheme increases commercial banks' stability.

It is not necessarily the case that deposit insurance impacts banks' risk-taking in the same way. Deposit insurance does affect bank risk-taking incentives, but it has different effects on each type of risk. Chi and Binh (2020) concluded from their research that 
credit, default, and leverage risk do have a negative relationship with deposit insurance, while leverage and deposit insurance have a positive relationship, which may help banks and supervisors when deciding what the deposit risk premium should be. Nizar and Mansur (2021) showed that big banks did not necessarily have better risk management compared to small banks. They concluded that under the risk-based deposit insurance scheme, banks with better risk management practices could be rewarded, while less prudent banks could be punished. In a pre-crisis study, Demirgüç-Kunt and Huizinga (2004) conducted a cross-country examination of deposit insurance systems and found that deposit insurance lowers banks' interest expenses as they become less sensitive to bank risk, by their deposit insurance coverage. Therefore, deposit insurance reduces market creditors and regulators' ability to instill market discipline on banks, which needs to be kept in mind when implementing a deposit insurance system.

The literature provides evidence about the importance of the appropriate levels of deposit insurance coverage and its role in mitigating bank runs. Research by Morrison and White (2011) advocates higher deposit insurance coverage when the banking sector is of poor or varying quality. The authors include a caveat that capital adequacy requirements must be imposed to prevent banks from being perversely encouraged by generous deposit insurance systems. In contrast, research by Kam Hon (2011) found that countries with lower coverage outperformed both high and fully covered deposits in maintaining financial stability. Furthermore, their empirical evidence showed that with higher coverage, the severity of the bank crisis increased. This reinforces the need to carefully evaluate coverage limits for deposit insurance to suit each jurisdiction, the quality of the finance system, and the economy. These studies highlight the concerns with deposit insurance coverage, but no research provides a definitive guide on what is an appropriate level of coverage. Instead, policymakers need to be aware that implementing deposit insurance systems requires significant preparation and investigation beforehand.

Recently, Boubaker et al. (2020) examined differences in bank efficiency using a fuzzy multi-objective two-stage data envelopment analysis technique. This entailed using data covering crisis periods from the Asian financial crisis (AFC) of the late 1990s to the GFC ${ }^{1}$ inclusive. They observed that banks affiliated with multi-bank holding companies are more efficient than those affiliated with single bank holding companies. Samet et al. (2018) noted that publicly traded banks are engaging in less risk-taking activities compared to private banks in the pre-crisis and post-crisis periods alike relative to post-crisis periods.

Thus, based on the literature reviewed, no significant work has been performed on investigating differences in the impact of deposit insurance schemes according to geographic regions. While work has been published on the origins of legal systems, such as incorporating variables for common law legal systems versus civil law systems, we have not come across research that investigates variations in economic maturity, institutional setup, and banking models. Secondly, in terms of timeframe, previous studies often looked at pre-crisis and post-crisis data to compare the impacts of a crisis on the relationships between deposit insurance and banking stability. However, we have not come across any research that examines the maturity of the deposit insurance system and its subsequent impact on a country's financial stability.

\section{Data and Methodology}

This paper aims to investigate the relationship between the level of deposit insurance coverage and banking stability in Asia and Europe by covering a data set from 61 jurisdictions for the period 2004-2014. Although there are 146 jurisdictions worldwide with deposit insurance systems, due to time and resource considerations, we have focused on 18 jurisdictions in Asia and 43 jurisdictions in Europe. The geographic data set provides us with an opportunity to assess the possibility of regional differences in the results. We selected this timeframe to obtain information before and after the GFC and, simultaneously, data covering ten years will provide sufficient inputs to the model. 
We hypothesized that indicators of banking sector stability would be strongly negatively associated with a banking crisis, especially bank z-score, non-performing loans, and bank concentration. We also postulate that banking crises should have a negative coefficient and be strongly associated with measures of banking competition in the banking sector (represented by the H-statistic) and banking profit efficiency (represented by the Boone indicator). If competition and efficiency are poor, we would expect a banking crisis is more likely to occur.

The empirical model shown in Equation (1) was tested using the pooled OLS method.

$$
B S_{i t}=\alpha_{i}+\beta_{1} D I C_{i t}+\beta_{2} M E_{i t}+\beta_{3} I E_{i t}+\beta_{4} D_{B C}+\varepsilon_{i t}
$$

In (1) above, $B S$ is the banking stability measure, DIC stands for deposit insurance coverage, $M E$ denotes macroeconomic variables, IE represents the institutional environmental variable, and $D_{B C}$ is a dummy for the banking crisis. Details of each measure are explained in Table 1. Data were obtained from the World Bank's Global Financial Development Database. The World Bank's development indicators (World Bank 2014a) and World Governance Indicators (World Bank 2014b) are themselves compendia of data from various sources such as the International Monetary Fund and Bankscope. We also used the Deposit Insurance Database 2014 (Demirgüç-Kunt et al. 2014b) for the characteristics of the deposit insurance systems of the sample jurisdictions.

Table 1. Summary of variables used in the empirical model.

\begin{tabular}{|c|c|c|}
\hline Proxy & Variables & Characteristics Captured by Variables \\
\hline Banking crisis $(\mathrm{BC})$ & $\begin{array}{c}\text { Crisis or no crisis (dummy variable, value of } 1 \text { if } \\
\text { there is a crisis and } 0 \text { otherwise) }\end{array}$ & $\begin{array}{l}\text { Experienced a banking crisis based on banking distress is } \\
\text { systemic if: (i) non-performing assets reached at least } 10 \% \text { of } \\
\text { total assets at the peak of the crisis, (ii) the fiscal cost of the } \\
\text { rescue operations was at least } 2 \% \text { of GDP, (iii) emergency } \\
\text { measures, such as bank holidays, deposit freezes, blanket } \\
\text { guarantees to depositors or other bank creditors, were taken } \\
\text { to assist the banking system, or (iv) if large-scale bank } \\
\text { nationalizations took place. }\end{array}$ \\
\hline $\begin{array}{l}\text { Deposit insurance } \\
\text { coverage (DIC) }\end{array}$ & $\begin{array}{c}\text { Coverage limit in US dollars (statutory limit, } \\
\text { converted in US dollars) based on GDP } \\
\text { (dummy variable, for low coverage, } 1 \text { if low, } 0 \\
\text { otherwise. For the high coverage, } 1 \text { if high, } \\
0 \text { otherwise) } \\
\text { Data only available as of 2003, 2010, } 2013 \\
\text { GDP growth (annual \%) }\end{array}$ & $\begin{array}{l}\text { Coverage limit in US dollars (statutory limit, converted in US } \\
\text { dollars) divided by the GDP per capita (constant } 2005 \text { US } \\
\text { dollars) to provide a measure of coverage limits against } \\
\text { relative jurisdiction of economic output. The average } \\
\text { coverage to GDP per capita of } 715 \% \text { as the cut-off into high } \\
\text { and low coverage. }\end{array}$ \\
\hline & $\begin{array}{l}\text { GDP per capita (constant } 2005 \text { USD) } \\
\text { Inflation, consumer prices (annual \%) }\end{array}$ & $\begin{array}{l}\text { Represent economic measures likely to affect the quality of } \\
\text { banking assets and the health of the banking system. }\end{array}$ \\
\hline $\begin{array}{l}\text { Macroeconomic } \\
\text { variables (ME) }\end{array}$ & $\begin{array}{c}\text { Money and quasi money (M2) as \% of GDP } \\
\text { Money and quasi money (M2) to total reserves ratio } \\
\text { Real interest rate (\%) } \\
\text { Risk premium on lending (lending rate minus } \\
\text { treasury bill rate, } \%)\end{array}$ & $\begin{array}{l}\text { Included here are economic factors that influenced banks' } \\
\text { cost of funds or profitability, capital outflows or foreign } \\
\text { exchange risk, and economic growth and development } \\
\text { (Ariff et al. 2021). }\end{array}$ \\
\hline & $\begin{array}{c}\text { S\&P Global Equity Indices (annual \% change) } \\
\text { Bank Z-score }\end{array}$ & \\
\hline Banking stability (BS) & $\begin{array}{c}\text { Bank nonperforming loans to gross loans (\%) } \\
\text { Regulatory capital to risk-weighted assets (\%) } \\
\text { Bank concentration (\%) } \\
\text { H-statistic (measure degree banking competition in } \\
\text { banking market) }\end{array}$ & $\begin{array}{l}\text { Captures the nature of stability including the concentration of } \\
\text { the banking sector, competition amongst banks, efficiency, } \\
\text { regulatory capital, and non-performing loans. }\end{array}$ \\
\hline & $\begin{array}{l}\text { Boone indicator (measure degree banking profit } \\
\text { efficiency) (Data from World Bank 2014a) }\end{array}$ & \\
\hline $\begin{array}{l}\text { Institutional } \\
\text { environment (IE) }\end{array}$ & $\begin{array}{c}\text { Political Stability } \\
\text { Government Effectiveness } \\
\text { Regulatory Quality } \\
\text { Rule of Law } \\
\text { Control of Corruption (Data from World Bank 2014b) }\end{array}$ & $\begin{array}{l}\text { Represents the institutional factors that can influence the } \\
\text { stability of the banking system as well as the health and } \\
\text { performance of the banks including political systems, a } \\
\text { strong judicial system, regulatory capabilities, transparency, } \\
\text { and corruption punished by the jurisdiction. }\end{array}$ \\
\hline
\end{tabular}




\section{Results and Discussion}

Looking at the descriptive statistics in Table 2, overall, we found there are differences between mean and median for most of the variables. This is likely because we have data available with us beforehand, during, and after the financial crisis. As well, our data set covers both European and Asian economies which are at different stages of economic development. Consequently, the banking stability measures also recorded a wide variation in mean and median, for similar reasons. The standard deviations we see in the variables reflect the differences amongst the jurisdictions in this study in terms of economic development, especially concerning GDP per capita, the coverage limits in dollars, and coverage limits vs. GDP. This illustrates the disparity amongst jurisdictions in setting their deposit insurance systems' coverage and how economic conditions influence how deposit insurance schemes are designed. Moreover, we observe large variations in institutional factors which we would expect as an area where jurisdictions with higher standards of governance would have more robust institutions compared to less-developed jurisdictions.

Table 2. Descriptive statistics for 61 jurisdictions with deposit insurance systems.

\begin{tabular}{|c|c|c|c|c|c|c|c|}
\hline Variable & Mean & Median & Min & Max & Q1 & Q3 & SD \\
\hline GDP growth & 3.0482 & 3.0694 & -14.814 & 17.2908 & 0.4501 & 5.6887 & 3.8805 \\
\hline GDP per capita constant 2005 (USD) & $20,006.3$ & $11,068.3$ & 0 & 117067 & -3284.6 & 25421.2 & $21,263.6$ \\
\hline Inflation & 3.6553 & 2.5687 & -4.4799 & 25.2964 & -0.0425 & 5.1798 & 3.8683 \\
\hline Money and quasi money M2 as of GDP & 32.0855 & 0 & 0 & 251.255 & -29.404 & 29.4041 & 43.5616 \\
\hline Money and quasi money M2 to total reserves & 2.0356 & 0 & 0 & 31.8684 & -2.5787 & 2.5787 & 3.8203 \\
\hline Real interest rate & 2.9683 & 2.2242 & -33.652 & 35.4151 & -1.2864 & 5.7347 & 5.2008 \\
\hline Risk premium on lending & 1.8058 & 0 & -5.644 & 21.0808 & -1.9703 & 1.9703 & 2.9189 \\
\hline S\&P Global equities & 10.077 & 0 & -82.19 & 189.23 & -22.421 & 22.4209 & 33.2161 \\
\hline Bank Z score & 9.4322 & 6.4466 & -6.1692 & 46.737 & -0.2795 & 13.1727 & 9.9646 \\
\hline Bank non-performing loans & 5.2407 & 2.9 & 0 & 59.757 & -1.7195 & 7.5195 & 6.8438 \\
\hline Regulatory Capital to Risk-Weighted Assets & 8.9741 & 11.5 & 0 & 32.2 & 5.99523 & 17.0048 & 8.1552 \\
\hline Bank Concentration & 44.33 & 49.8956 & 0 & 100 & 25.8147 & 73.9765 & 35.6754 \\
\hline H-statistic & 0.0404 & 0 & -0.0194 & 1.255 & -0.1091 & 0.1091 & 0.1616 \\
\hline Boone indicator & -0.0116 & -0.0134 & -0.6517 & 2.9239 & -0.1668 & 0.1400 & 0.2273 \\
\hline Coverage limit in US dollars & $61,097.8$ & 22,727 & 0 & 0 & -54438 & $99,892.3$ & 114,319 \\
\hline Political Stability & 72.651 & 81.6901 & 0 & 100 & 62.3309 & 101.049 & 28.6803 \\
\hline Government Effectiveness & 75.9003 & 82.5665 & 0 & 100 & 67.3199 & 97.8131 & 22.5876 \\
\hline Regulatory Quality & 76.1015 & 85.3716 & 0 & 100 & 69.2671 & 101.476 & 23.8585 \\
\hline Rule of Law & 73.3229 & 78.0428 & 15.7143 & 100 & 62.4388 & 93.6468 & 23.117 \\
\hline Control of Corruption & 71.2319 & 71.9048 & 10.1942 & 100 & 56.2982 & 87.5114 & 23.1209 \\
\hline Coverage vs. GDP (USD) & 169.019 & 147.5 & 1 & 431 & 60.3278 & 234.672 & 129.144 \\
\hline Coverage vs. GDP per capita & 1.4417 & 1 & 1 & 3 & 0.51404 & 1.4860 & 0.7199 \\
\hline Crisis & 0.0296 & 0 & 0 & 1 & -0.1144 & 0.1144 & 0.1695 \\
\hline Low deposit insurance coverage & 0.6938 & 1 & 0 & 1 & 0.6887 & 1.3113 & 0.4612 \\
\hline
\end{tabular}

Notes: (i) Quartiles are calculated using following formulas Q1 = Median $-(0.675) \times$ SD and Q3 = Median $+(0.675) \times$ SD. (ii) SD stands for standard deviation.

\subsection{Model 1 Holistic Model-Banking Stability and the Relationships with Macroeconomic Conditions and Institutional Health}

For the holistic model, we took the entire sample data set and regressed each of the stability variables on the various economic and institutional variables with crisis and deposit insurance coverage dummies in our models. Models include country-fixed effects. The findings are shown in Table 3. 
Table 3. Holistic model-banking stability, economic factors, and institutional environment.

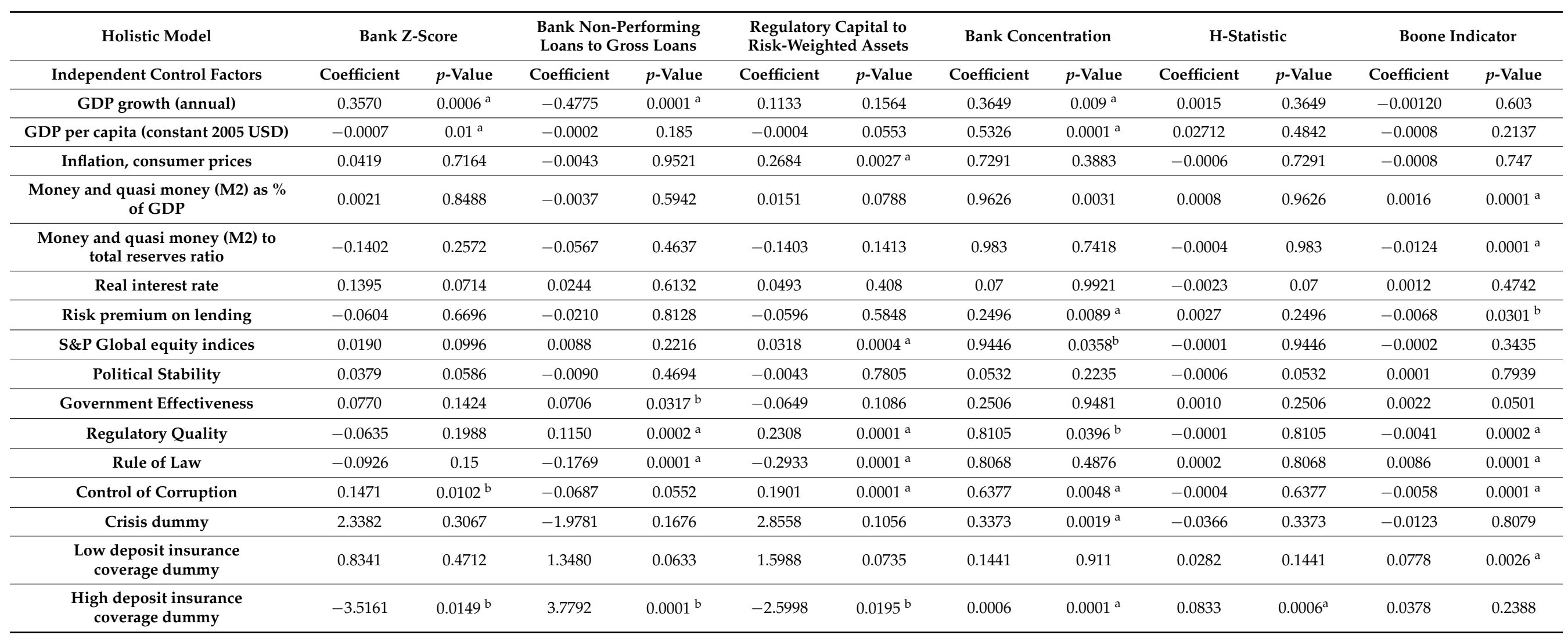

Notes: (i) R square: 0.8921 ; adjusted R square: 0.8364 ; F-statistics $=164.877$, (ii) $p$-value is significant if it is less than $5 \%$, ${ }^{\text {a }}$ and ${ }^{\mathrm{b}}$ represent significance at the $1 \%$ and $5 \%$ threshold levels, respectively. 
The significant correlation for GDP growth and GDP per capita across several stability measures for economies with deposit insurance systems is supported by Hutchison (2002) who, in a study of European economies, found that real output growth was correlated with the banking sector crisis. However, for regulatory capital to risk-weighted assets (RCRW) or non-performing loans (NPL), we expected to see a significant association with GDP measures. In contrast to prior studies of bank performance and economic factors, our results did not find several significant relationships amongst other economic factors such as inflation, interest rates, and monetary measures.

Another interesting result was that the bank concentration stability measure had a significant number of associations with economic factors. It raises the question of the presence of deposit insurance increasing the correlation between banking concentration and financial system stability. In other studies of banking crises, the results have been ambiguous between bank concentration and stability. Beck et al. (2006) illustrated that more concentrated banking sectors are less likely to experience a crisis while Schaeck et al. (2009) held a contrary view. Consequently, this raises the question of deposit insurance increasing the effect of economic factors on banking stability when taking bank size into account. This lends credence to the argument that deposit insurance increases the risk which banks are willing to take and moral hazard coming into play with banks assuming they can take further risk. Here the assumption is that they are 'too big to fail'.

Regulatory quality, rule of law and corruption are found to be associated with financial stability in the holistic model. Anginer et al. (2014) found that in jurisdictions with deposit insurance, high-quality bank supervision is associated with lower systemic banking risk while poor quality regulatory quality can undermine the financial stability of jurisdictions with deposit insurance, giving credibility to our findings. Low deposit insurance coverage has only one positive association with a stability measure. This suggests there is not a strong relationship between banking stability and low deposit insurance. In contrast, high deposit insurance coverage has significant associations with five out of six stability measures. However, we note that for two of our stability measures, there is a large negative coefficient, meaning that the high deposit insurance coverage has a strong adverse effect on financial stability. These results are similar to Demirgüç-Kunt and Detragiache (2002) in their analysis of explicit deposit insurance, where more extensive deposit insurance wielded a stronger impact on financial stability.

\subsection{Model II Regional-Banking Stability and the Relationships with Macroeconomic Conditions and Institutional Health}

As for our regional models, we partitioned our sample into Model 2 (I) European deposit insurance systems and Model 2 (II) Asian deposit insurance systems. We discuss our results in the following sections starting with the European model.

\subsection{Model 2 (I) Regional Model for Europe-Banking Stability and Relationships with} Macroeconomic Conditions and Institutional Health

Table 4 below presents the results of the European model, and so we took the European sample data set and regressed each stability variable on the various economic and institutional variables with crisis and deposit insurance coverage dummies in our model. Models include country-fixed effects. In the table presented here, each column stands for one stability variable and represents a separate regression. 
Table 4. Europe-banking stability, economic factors, and institutional environment.

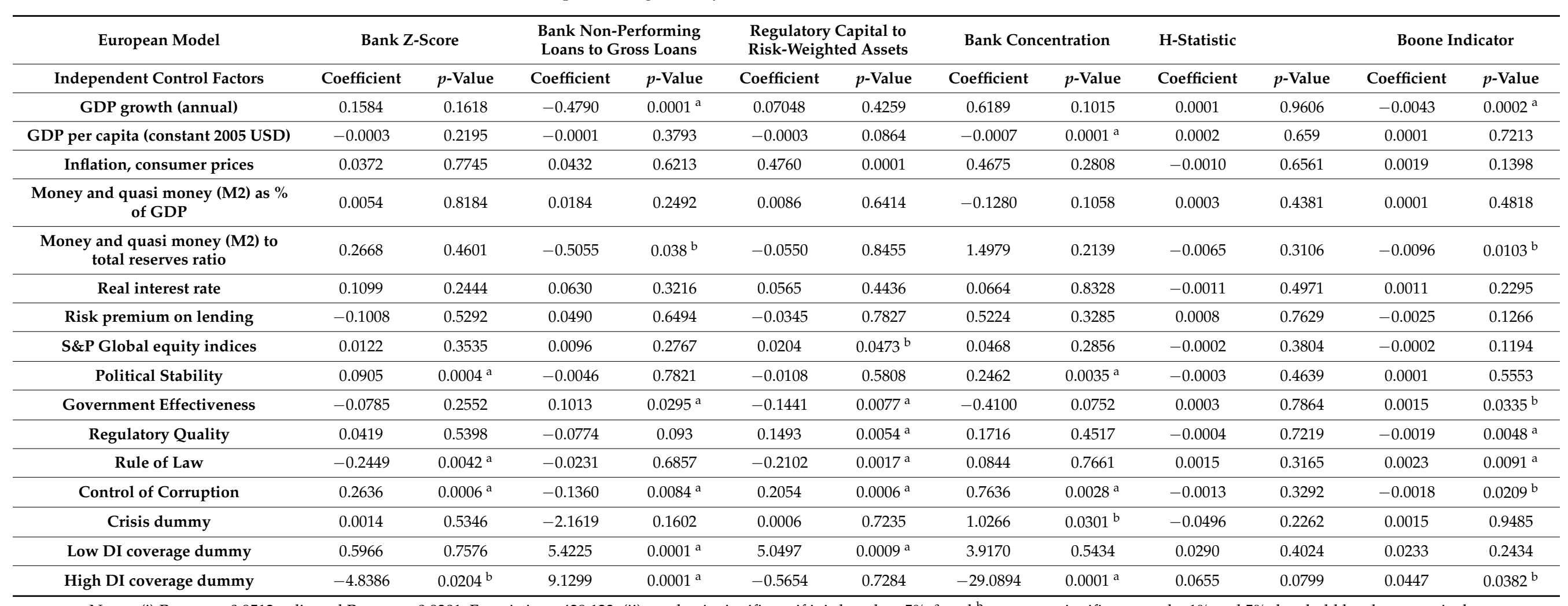

Notes: (i) R square: 0.9512; adjusted R square: 0.9301 ; F-statistics $=429.123$, (ii) $p$-value is significant if it is less than $5 \%$, ${ }^{\mathrm{a}}$ and ${ }^{\mathrm{b}}$ represent significance at the $1 \%$ and $5 \%$ threshold levels, respectively. 
Like the holistic model, the European model detected significance between regulatory risk-weighted assets and stock market performance, while for GDP growth, GDP per capita, and money and M2 to total reserves ratio, we found strong associations with bank non-performing loans, bank concentration, and the Boone indicator. We did not expect a negative coefficient for GDP growth and GDP per capita, as this implies increased growth in GDP leading to poorer banking sector stability. This result is counter to what previous studies documented. Moreover, we had expected more associations between the economic factors as we had found in our holistic model and noted by Hutchison (2002) and Gavin and Ricardo (1996). One study covering Germany's banking sector, one of the largest and most economically powerful European countries, reported the existence of a relationship between bank distress and monetary policy (De Graeve et al. 2008). We infer that European deposit insurance systems have provided a certain amount of insulation from economic conditions on banking sector stability.

In contrast to the holistic model, we found significant positive relationships amongst the stability measures with political stability and more significant associations with government effectiveness in the European model. This is in line with findings by Grilli et al. (1991) who showed that political instability led to higher public debt and inflation, resulting in financial instability in more advanced economies, such as those in Europe. In the European model, we found fewer significant associations with regulatory quality while we found a similar number of associations with rule of law and corruption as our holistic model. However, unlike the holistic model, we discovered a slight majority of negative correlations in our associations, which means that with better regulators or legal systems, an improvement in financial stability will occur. This differs from Anginer et al. (2014) who found that in jurisdictions with deposit insurance, high-quality bank supervision is associated with lower systemic banking risk while poor quality regulatory quality can endanger financial stability.

The results of the European model are comparable to the holistic model with high negative coefficients with stability scores, indicating that high deposit insurance coverage has a strong negative impact on banking system stability. In contrast, low coverage limits have only one positive association with stability measures, and the European model results contribute to the argument that higher levels of deposit insurance coverage contribute to banking fragility (Demirgüç-Kunt and Detragiache 2002). Referring to the institutional factors, our findings for the European model differ from our holistic model. The results also contradict Barros et al. (2007) and Demirgüç-Kunt and Detragiache (2002) who found evidence that the institutional environment was positively associated with banking stability. For this reason, we are inclined to go back to the results of our holistic model and support literature confirming that a strong institutional environment is positively related to banking stability.

The European model reinforces our holistic model findings and evidence in the literature that high deposit insurance coverage is strongly and negatively associated with banking stability measures. Policymakers have to set coverage parameters that are believed and trusted by depositors and cover a significant majority of customers while leaving a large enough proportion exposed to market discipline (IADI 2014).

\subsection{Model 2 (II) Regional Model for Asia-Banking Stability and the Relationships with Macroeconomic Conditions and Institutional Health}

For the Asian model, we took the sample data set and regressed each of the stability variables on the various economic and institutional variables with crisis and deposit insurance coverage dummies in our models. Models include country-fixed effects. Results are shown in Table 5. 
Table 5. Asian model-banking stability, economic factors, and institutional environment.

\begin{tabular}{|c|c|c|c|c|c|c|c|c|c|c|c|c|}
\hline \multirow{2}{*}{$\begin{array}{c}\text { Asian Model } \\
\text { Independent Control Factors }\end{array}$} & \multicolumn{2}{|c|}{ Bank Z-Score } & \multicolumn{2}{|c|}{$\begin{array}{l}\text { Bank Non-Performing } \\
\text { Loans to Gross Loans }\end{array}$} & \multicolumn{2}{|c|}{$\begin{array}{l}\text { Regulatory Capital to } \\
\text { Risk-Weighted Assets }\end{array}$} & \multicolumn{2}{|c|}{ Bank Concentration } & \multicolumn{2}{|c|}{ H-Statistic } & \multicolumn{2}{|c|}{ Boone Indicator } \\
\hline & Coefficient & $p$-Value & Coefficient & $p$-Value & Coefficient & $p$-Value & Coefficient & $p$-Value & Coefficient & $p$-Value & Coefficient & $p$-Value \\
\hline GDP growth (annual) & 0.3649 & 0.1735 & 0.0773 & 0.4324 & 0.2581 & 0.145 & 1.8196 & $0.0194^{\mathrm{b}}$ & 0.0145 & $0.0008^{a}$ & 0.0008 & 0.9395 \\
\hline GDP per capita (constant 2005 USD) & -0.0006 & $0.0001^{\mathrm{a}}$ & -0.0001 & $0.0024^{\mathrm{a}}$ & 0.0001 & 0.2785 & 0.0002 & 0.5663 & 0.0003 & 0.1768 & -0.0006 & 0.2764 \\
\hline Inflation, consumer prices & 0.0629 & 0.8046 & -0.1783 & 0.0577 & -0.3007 & 0.0745 & 0.3577 & 0.6267 & 0.0006 & 0.8793 & 0.0016 & 0.8672 \\
\hline $\begin{array}{c}\text { Money and quasi money (M2) as \% } \\
\text { of GDP }\end{array}$ & -0.0259 & 0.0894 & 0.0031 & 0.5791 & 0.0087 & 0.3853 & -0.0214 & 0.6263 & 0.0004 & 0.8638 & 0.0019 & $0.0016^{\mathrm{a}}$ \\
\hline Real interest rate & 0.0771 & 0.5637 & 0.0857 & 0.082 & -0.0180 & 0.8376 & 0.0473 & 0.9023 & -0.0044 & $0.0401^{b}$ & 0.00216 & 0.6844 \\
\hline Risk premium on lending & 0.1420 & 0.6022 & -0.2215 & $0.028^{\mathrm{b}}$ & -0.0197 & 0.9128 & 3.1252 & $0.0001^{\mathrm{a}}$ & 0.0027 & 0.5293 & -0.0155 & 0.1528 \\
\hline S\&P Global equity indices & 0.0131 & 0.5326 & 0.0108 & 0.1617 & 0.0213 & 0.1256 & 0.0659 & 0.2796 & 0.0006 & 0.0518 & -0.0005 & 0.9951 \\
\hline Political Stability & -0.0087 & 0.8222 & -0.0085 & 0.5483 & -0.0700 & $0.0066^{\mathrm{a}}$ & -0.1669 & 0.1372 & -0.0006 & 0.3287 & 0.0007 & 0.6297 \\
\hline Government Effectiveness & 0.3000 & $0.0014^{\mathrm{a}}$ & 0.0493 & 0.1486 & 0.2470 & $0.0001^{\mathrm{a}}$ & 0.4467 & 0.0965 & 0.0007 & 0.5925 & -0.0006 & 0.8589 \\
\hline Regulatory Quality & -0.1501 & 0.204 & 0.0442 & 0.308 & -0.1081 & 0.1661 & -0.5027 & 0.1415 & -0.0001 & 0.9514 & -0.0003 & 0.9426 \\
\hline Control of Corruption & 0.0316 & 0.7536 & -0.0312 & 0.4001 & -0.1109 & 0.0967 & -0.3013 & 0.3016 & 0.0019 & 0.2177 & -0.0083 & $0.0386^{\mathrm{b}}$ \\
\hline Low DI coverage dummy & -0.5303 & 0.8199 & -2.8466 & 0.001 & -1.48621 & 0.3344 & -24.5254 & 0.0003 & 0.156103 & 0.0001 & -0.000294294 & 0.9975 \\
\hline High DI coverage dummy & 2.4922 & 0.1681 & -0.0910 & 0.8909 & -3.9753 & $0.001^{\mathrm{a}}$ & -21.9013 & $0.0001^{\mathrm{a}}$ & 0.04175 & 0.1486 & 0.1886 & $0.0093^{a}$ \\
\hline
\end{tabular}

Notes: (i) R square: 0.9364 ; adjusted R square: 0.9123 ; F-statistics $=474.825$, (ii) $p$-value is significant if it is less than $5 \%$, ${ }^{\text {and }}{ }^{\mathrm{b}}$ represent significance at the $1 \%$ and $5 \%$ threshold levels, respectively. 
The Asian model results for economic factors are closer to those of the holistic model, especially when compared to the European model. We found a significant difference between GDP growth and two stability measures, as well as for GDP per capita and two more stability measures. However, for GDP per capita, the coefficient is negative and this indicates GDP growth results in more instability, which contradicts other research (Hutchison 2002) and the holistic model results. We see that for Asian jurisdictions, money supply and monetary policy are significantly associated with several stability measures. This is supported by De Graeve et al. (2008) in their work on the German banking system, and they discovered a greater likelihood of banking distress due to monetary policy. However, unlike our holistic or European model, there were no significant associations with the stock market return.

We had expected stock market returns to influence banking stability considering the results in our holistic model and the work of Schaeck et al. (2009), who noted that a well-developed stock market provides a good source of funding for banks, so it may lead to a more sophisticated banking sector. Political stability is only significantly associated with one stability measure and carries a negative coefficient. This contrasts with the work by Grilli et al. (1991) and our findings in the European model. While political stability may seem to be less important to the financial stability for Asian jurisdictions, government effectiveness for Asia has two significant positive associations, which means the influence of government on financial stability cannot be dismissed.

There was also no significant associations for regulatory quality and only one association for corruption, in contrast to our holistic model, the European model and Anginer et al. (2014) work. Further validating the literature and our findings for our holistic and European model, the rule of law is strongly positively associated with several stability measures. The results for the Asian model's institutional factors tell us that these variables are less important to financial stability compared to our holistic or European model. This could be explained by two things: firstly, the level of development; and secondly, the maturity of these institutions in Asia compared to Europe.

In the Asian model, we found there are significant associations with low coverage and high coverage where most coefficients are negative for both types of coverage. This differs from our holistic and European models where we found clearer relationships with high deposit insurance coverage diminishing banking stability, which was backed up by earlier research (Demirgüç-Kunt and Detragiache 2002). This means the level of coverage is more ambiguous for Asian deposit insurers and while we can rationalize the link between high deposit coverage and moral hazard increasing banks risk-taking, explaining the reason for increased banking instability due to lower deposit insurance coverage is harder to do.

4.5. Model 3 Time Since the Establishment of a Deposit Insurance System-Banking Stability and the Relationships with Macroeconomic Conditions and Institutional Health

Referring to our dates for when our models were established, we separated our sample into deposit insurance systems established between 1961 and 1985, and 1987 and 2013, Model 3 (I) and Model 3 (II), respectively.

4.6. Model 3 (I) Deposit Insurance System Established between 1961 and 1985-Banking Stability and the Relationships with Macroeconomic Conditions and Institutional Health

For Model 3 (I) or the "mature" model, we regressed each stability measure against the selected economic and institutional environment control factors with crisis and deposit insurance coverage dummies as shown in Table 6. Models include country-fixed effects. 
Table 6. Date of establishment (1961-1985)-banking stability, economic factors, and institutional environment.

\begin{tabular}{|c|c|c|c|c|c|c|c|c|c|c|c|c|}
\hline \multirow{3}{*}{$\begin{array}{l}\text { Mature Model } \\
\text { Independent Control Factors }\end{array}$} & \multirow{2}{*}{\multicolumn{2}{|c|}{$\begin{array}{c}\text { 1961-1985 } \\
\text { Bank Z Score }\end{array}$}} & \multirow{2}{*}{\multicolumn{2}{|c|}{$\begin{array}{c}\text { 1961-1985 } \\
\text { Bank Non-Performing } \\
\text { Loans to Gross Loans }\end{array}$}} & \multirow{2}{*}{\multicolumn{2}{|c|}{$\begin{array}{c}\text { 1961-1985 } \\
\text { Regulatory Capital to } \\
\text { Risk-Weighted Assets }\end{array}$}} & \multicolumn{2}{|c|}{ 1961-1985 } & \multicolumn{2}{|c|}{ 1961-1985 } & \multicolumn{2}{|c|}{ 1961-1985 } \\
\hline & & & & & & & \multicolumn{2}{|c|}{ Bank Concentration } & \multicolumn{2}{|c|}{ H-Statistic } & \multicolumn{2}{|c|}{ Boone Indicator } \\
\hline & Coefficient & $p$-Value & Coefficient & $p$-Value & Coefficient & $p$-Value & Coefficient & $p$-Value & Coefficient & $p$-Value & Coefficient & $p$-Value \\
\hline GDP growth (annual) & 0.8208 & $0.0022^{\mathrm{a}}$ & -0.4023 & $0.0001^{\mathrm{a}}$ & 0.3228 & 0.0528 & 0.0604 & 0.9433 & 0.0057 & 0.1427 & -0.0146 & $0.0001^{\mathrm{a}}$ \\
\hline GDP per capita (constant 2005 USD) & -0.0001 & $0.0303^{\mathrm{b}}$ & 0.0002 & 0.3168 & -0.0001 & $0.0151^{\mathrm{b}}$ & 0.0002 & 0.3042 & 0.0007 & 0.567 & 0.0009 & 0.2086 \\
\hline Inflation, consumer prices & -0.4976 & 0.0862 & 0.1457 & 0.0753 & 0.6123 & 0.0008 & 1.5531 & 0.0949 & 0.0002 & 0.9491 & 0.0122 & $0.0001^{\mathrm{a}}$ \\
\hline $\begin{array}{l}\text { Money and quasi money (M2) as \% } \\
\text { of GDP }\end{array}$ & 0.0548 & 0.0797 & -0.0134 & 0.1265 & -0.0069 & 0.7222 & -0.0396 & 0.6916 & 0.0002 & 0.5544 & 0.0013 & $0.0001^{\mathrm{a}}$ \\
\hline $\begin{array}{l}\text { Money and quasi money (M2) to } \\
\text { total reserves ratio }\end{array}$ & -1.6312 & $0.0055^{\mathrm{a}}$ & 0.3308 & $0.045^{\mathrm{b}}$ & 0.0071 & 0.9844 & -2.1267 & 0.2546 & -0.0023 & 0.7825 & -0.0262 & $0.0001^{\mathrm{a}}$ \\
\hline Real interest rate & 0.6206 & $0.0173^{\mathrm{b}}$ & -0.0367 & 0.6151 & -0.0511 & 0.7522 & -0.1378 & 0.8681 & -0.0040 & 0.2869 & -0.0005 & 0.8181 \\
\hline Risk premium on lending & -1.4650 & $0.0046^{\mathrm{b}}$ & 0.2012 & 0.1644 & 0.7218 & $0.0249^{b}$ & 0.7461 & 0.6491 & -0.0023 & 0.7531 & 0.0066 & 0.1454 \\
\hline S\&P Global equity indices & 0.026 & 0.2665 & 0.0060 & 0.3788 & 0.0239 & 0.1144 & 0.1371 & 0.0775 & -0.0002 & 0.5558 & -0.0001 & 0.5321 \\
\hline Political Stability & -0.0537 & 0.3576 & -0.0116 & 0.4812 & 0.0210 & 0.5643 & 0.3173 & 0.091 & -0.0009 & 0.2924 & 0.0007 & 0.158 \\
\hline Government Effectiveness & 0.2901 & $0.0335^{\mathrm{b}}$ & 0.0690 & 0.073 & 0.0325 & 0.7019 & 0.00415 & 0.9924 & 0.0026 & 0.1931 & -0.0006 & 0.5656 \\
\hline Rule of Law & 0.1935 & 0.3464 & 0.0310 & 0.5921 & -0.1659 & 0.1973 & -1.3570 & $0.0404^{\mathrm{b}}$ & 0.0020 & 0.5022 & 0.0007 & 0.6935 \\
\hline Control of Corruption & -0.2712 & $0.0388^{\mathrm{b}}$ & -0.1090 & $0.0034^{\mathrm{a}}$ & 0.1289 & 0.1155 & 0.1045 & 0.8028 & -0.0019 & 0.3163 & -0.0010 & 0.3494 \\
\hline Crisis dummy & -3.2683 & 0.4551 & 3.0276 & $0.015^{b}$ & 1.5151 & 0.5798 & 25.1991 & 0.0735 & -0.1247 & 0.0538 & 0.0584 & 0.1331 \\
\hline Low DI coverage dummy & -0.0007 & 0.9998 & -0.6738 & 0.5472 & 0.7769 & 0.7539 & 28.1429 & $0.0277^{b}$ & -0.0494 & 0.3969 & 0.0387 & 0.2713 \\
\hline High DI coverage dummy & - & - & - & - & - & - & - & - & - & - & - & - \\
\hline
\end{tabular}

High DI coverage dummy

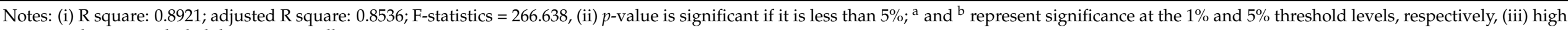
coverage dummy excluded due to exact collinearity. 
We detected a significant correlation between GDP growth and GDP per capita in our mature time model with significant associations with five stability measures. The relationship with these economic control factors is stronger compared to the holistic, Asian, and European models but the results do agree with the literature, for example, Hutchison (2002) and Gavin and Ricardo (1996). However, as we saw for our European model, we have negative coefficients for GDP which tells us that economic growth simply increases fragility in the banking system. Again, this is contrary to our expectations and suggests that deposit insurance systems may be changing the expected relationships here.

The results for the mature model fit more with findings by authors on economic factors (De Graeve et al. 2008). The mature model shows significant associations with stability measures for money supply and monetary policy such as money reserves, interest rate, and the risk premium on lending and inflation. This fits more with our expectations, but we still found negative and positive correlations for the same economic factor, such as risk premium on lending, which is positively associated with RCWR. However, it is negatively associated with bank Z-score. This emphasizes the need to examine a range of stability measures in any assessment of banking stability.

The mature time-based model reveals significant associations for all the above institutional factors although they do not occur frequently amongst our five stability measures. Only control of corruption had more than one significance, with bank Z-score and bank non-performing loans. Notably, the associations were all negative except for regulator quality. This is very different from Anginer et al. (2014) and Demirgüç-Kunt and Detragiache (2002), who found jurisdictions with deposit insurance and stronger institutional factors will have better financial stability. We found only one instance of significance with bank concentration and low deposit insurance coverage, while we have excluded high deposit insurance due to exact collinearity in the model. A possibility for collinearity existing was that our sample was not large enough, as out of the twenty mature jurisdictions in Model 3 (I), only five jurisdictions had high levels of coverage. The trend for increased levels of coverage is a more recent phenomenon, so it is arguable that established deposit insurers have taken more time to increase their deposit insurance coverage levels.

4.7. Model 3 (II) Deposit Insurance System Established between 1987 and 2013-Banking Stability and the Relationships with Macroeconomic Conditions and Institutional Health

For Model 3 (II) or the "contemporary" model, we regressed all stability measures against the selected economic and institutional environment control factors with crisis and deposit insurance coverage dummies as shown in Table 7. Models include countryfixed effects. 
Table 7. Date of establishment (1987-2013)-banking stability, economic factors, and institutional environment.

\begin{tabular}{|c|c|c|c|c|c|c|c|c|c|c|c|c|}
\hline \multirow{3}{*}{$\begin{array}{c}\text { Contemporary Model } \\
\text { Independent Control Factors }\end{array}$} & \multirow{2}{*}{\multicolumn{2}{|c|}{$\begin{array}{c}\text { 1987-2013 } \\
\text { Bank Z Score }\end{array}$}} & \multirow{2}{*}{\multicolumn{2}{|c|}{$\begin{array}{c}\text { 1987-2013 } \\
\text { Bank Non-Performing } \\
\text { Loans to Gross Loans }\end{array}$}} & \multirow{2}{*}{\multicolumn{2}{|c|}{$\begin{array}{c}1987-2013 \\
\text { Regulatory Capital to } \\
\text { Risk-Weighted Assets }\end{array}$}} & \multirow{2}{*}{\multicolumn{2}{|c|}{$\begin{array}{c}\text { 1987-2013 } \\
\text { Bank Concentration }\end{array}$}} & \multirow{2}{*}{\multicolumn{2}{|c|}{$\begin{array}{r}1987-2013 \\
\text { H-Statistic }\end{array}$}} & \multicolumn{2}{|c|}{ 1987-2013 } \\
\hline & & & & & & & & & & & Boone $\mathrm{Ir}$ & licator \\
\hline & Coefficient & $p$-Value & Coefficient & $p$-Value & Coefficient & $p$-Value & Coefficient & $p$-Value & Coefficient & $p$-Value & Coefficient & $p$-Value \\
\hline GDP growth (annual) & 0.1811 & 0.0778 & -0.5506 & $0.0001^{\mathrm{a}}$ & 0.0734 & 0.4351 & 1.0130 & 0.0056 & 0.0008 & 0.6637 & 0.0021 & 0.4644 \\
\hline GDP per capita (constant 2005 USD) & -0.0003 & 0.9039 & -0.0004 & 0.0552 & -0.0004 & 0.0944 & -0.0007 & $0.0001^{\mathrm{a}}$ & 0.0002 & 0.6495 & -0.0006 & 0.4197 \\
\hline Inflation, consumer prices & 0.2736 & $0.0173^{\mathrm{b}}$ & -0.0608 & 0.4984 & 0.2108 & $0.0453^{b}$ & 0.0419 & 0.9179 & -0.0007 & 0.7397 & -0.0024 & 0.4533 \\
\hline $\begin{array}{l}\text { Money and quasi money (M2) as \% } \\
\text { of GDP }\end{array}$ & 0.0584 & $0.0001^{\mathrm{a}}$ & -0.0095 & 0.3577 & 0.0256 & $0.0346^{\mathrm{a}}$ & -0.0994 & $0.0347^{\mathrm{b}}$ & -0.0008 & 0.7379 & 0.00230 & $0.0001^{\mathrm{a}}$ \\
\hline $\begin{array}{c}\text { Money and quasi money (M2) to } \\
\text { total reserves ratio }\end{array}$ & -0.3095 & $0.01^{\mathrm{a}}$ & -0.1259 & 0.1802 & -0.1462 & 0.1836 & 0.1300 & 0.7599 & 0.0007 & 0.7527 & -0.0118 & $0.0004^{\mathrm{a}}$ \\
\hline Real interest rate & 0.1278 & 0.0855 & 0.0049 & 0.9322 & 0.036641 & 0.5905 & 0.05316 & 0.8403 & -0.0020 & 0.1686 & 0.0022 & 0.2703 \\
\hline Risk premium on lending & 0.1824 & 0.1775 & -0.0557 & 0.599 & -0.1342 & 0.2792 & 0.8285 & 0.0849 & 0.0028 & 0.2919 & -0.0087 & $0.0217^{b}$ \\
\hline S\&P Global equity indices & 0.0109 & 0.3597 & 0.0124 & 0.1814 & 0.0344 & $0.0017^{\mathrm{a}}$ & 0.0627 & 0.1389 & 0.0001 & 0.6692 & -0.0002 & 0.3874 \\
\hline Political Stability & 0.1308 & $0.0001^{\mathrm{a}}$ & -0.0058 & 0.7521 & 0.0120 & 0.5761 & 0.0755 & 0.3676 & -0.0007 & 0.1228 & -0.0005 & 0.4049 \\
\hline Government Effectiveness & 0.0153 & 0.7833 & 0.0179 & 0.6817 & -0.1011 & $0.0484^{\mathrm{a}}$ & -0.2983 & 0.1327 & 0.0007 & 0.4824 & 0.0030 & 0.0529 \\
\hline Rule of Law & -0.2947 & $0.0001^{\mathrm{a}}$ & -0.1535 & $0.0034^{\mathrm{a}}$ & -0.2897 & $0.0001^{\mathrm{a}}$ & 0.2053 & 0.3863 & 0.0005 & 0.6505 & 0.0120 & $0.0001^{\mathrm{a}}$ \\
\hline Control of Corruption & 0.3411 & $0.0001^{\mathrm{a}}$ & -0.0189886 & 0.6883 & 0.183825 & 0.001 & 0.624473 & 0.0037 & -0.000302762 & 0.799 & -0.00756767 & 0.0001 \\
\hline Crisis dummy & -4.47011 & 0.0011 & 5.0406 & $0.000^{\mathrm{a}}$ & -2.9541 & $0.0188^{b}$ & -27.1565 & $0.0001^{\mathrm{a}}$ & 0.0930 & $0.0006^{\mathrm{a}}$ & 0.05307 & 0.1658 \\
\hline Low DI coverage dummy & 3.0396 & 0.2339 & -2.2248 & 0.2664 & 1.1931 & 0.2437 & 20.2459 & $0.0259^{b}$ & -0.0263 & 0.6004 & -0.0558 & 0.434 \\
\hline High DI coverage dummy & -0.8307 & 0.4564 & 1.4418 & 0.0995 & 3.5899 & 0.1255 & 2.7082 & 0.4944 & 0.0354 & 0.1066 & 0.1293 & $0.0001^{\mathrm{a}}$ \\
\hline
\end{tabular}

Notes: (i) R square: 0.8714 ; adjusted R square: 0.8432 ; F-statistics $=218.528$, (ii) $p$-value is significant if it is less than $5 \%$, ${ }^{a}$ and ${ }^{\mathrm{b}}$ represent significance at the $1 \%$ and $5 \%$ threshold levels, respectively. 
We observed significant associations with GDP growth and GDP per capita in our contemporary time model, amongst two out of five stability measures. Compared to our mature time model, we have fewer associations with GDP and banking stability. This is more in line with the findings of our holistic, Asian, and European models. However, as discussed for our mature and European models, we have negative coefficients for GDP and this inverse relationship contrasts with our hypotheses and the literature. However, there were fewer associations with the interest rate, the risk premium on lending, inflation, and the stock market that other studies such as including those by Hutchison (2002) and Gavin and Ricardo (1996), which were related to banking stability. As with our other models, we see a mix of positive and negative associations.

Our contemporary model results closely follow the findings in our mature model with minimal significant associations of political stability and government effectiveness. This is much lower compared to our holistic or regional models or in other studies such as Grilli et al. (1991), which indicates strong relationships between banking stability and political stability or government effectiveness. We detected two positive associations with regulator quality and only one negative association. This is more in line with work undertaken by Anginer et al. (2014), revealing the positive impact of high-quality regulators on banking stability.

In contrast to Barros et al. (2007) on legal institutions, the rule of law is negatively correlated with two stability measures and only positively associated with one. Nonetheless, our findings for corruption show several significant positive associations with stability measures, which is supported by Demirgüç-Kunt and Detragiache (2002) who highlighted the importance of a good institutional environment in contributing to banking stability. We have based our model and variable selections on theory and related empirical research in deposit insurance. Our contemporary model provides limited evidence with the association between banking stability and low or high deposit insurance coverage, with only one positive association for each of our control factors. This contrasts with Barth et al. (2004) and Demirgüç-Kunt and Detragiache (2002), where their results showed that, firstly, higher coverage limits in deposit insurance systems may encourage moral hazard; and secondly, banks take on higher risks for higher returns, thus compromising banking stability.

We see that monetary policy and money supply had the most significant number of associations amongst economic factors. In the years following the GFC, central banks applied monetary policies and used tools such as quantitative easing to stimulate the economy (Stark 2009). Compared to the mature deposit insurance systems, economic conditions exert a greater influence on banking stability for newer deposit insurance systems. This could mean that over time, as deposit insurance matures and the public sees that deposit insurance is effective through successful pay-outs during bank failures or timely intervention and resolution of troubled banks, confidence is boosted in the deposit insurance system and the ability to combat worsening economic conditions.

Turning to our institutional environment control factors, we found fewer associations between banking stability and institutional environmental factors compared to previous literature. During the period, the regulatory trend tilted towards deregulation while the rise of innovative financial products meant that the institutional environment was less important (Stark 2009). This may explain the weaker associations since younger deposit insurers may not have been afforded the full range of powers in an environment when deregulation dominated. Nevertheless, throughout our different models, the results reinforce the need to conduct further investigation into the institutional environment and relationships with deposit insurance. Anginer et al. (2014) found that good regulatory and institutional frameworks, including supervision, kept the moral hazard arising from deposit insurance in check and promoted the stabilization benefits of deposit insurance. In terms of coverage limits, our findings contradict the results of prior research in this area on deposit insurance, as we found limited significance between stability and coverage limits for our contemporary model. However, the results for our other models, such as the holistic model and the regional models, are more closely related to the literature. We 
interpret this to mean that how contemporary deposit insurance systems are designed may resolve the moral hazard problem that is created by deposit insurance. This could be done by concerted efforts following the GFC by deposit insurers to follow best practice features recommended by IADI. Included here, for example, are risk-adjusted premiums, appropriate intervention, and resolution powers that mitigate the moral hazard of deposit insurance (IADI 2014).

\section{Concluding Remarks}

Deposit insurance systems were implemented in more jurisdictions following the global financial crisis as governments and policymakers had to find ways to maintain financial stability and resolve this problem urgently. During the GFC, a policy response to financial instability was to expand deposit insurance coverage, with temporary blanket guarantees on all deposits becoming commonplace, while jurisdictions without existing deposit insurance systems had to move quickly to set up coverage (Anginer et al. 2014).

The reaction by policymakers during the financial crisis underlines the importance of deposit insurance and its effects, either positive or negative, on financial stability. Therefore, this study seeks to understand the arguments relating to deposit insurance and analyze empirical evidence to determine the effects of deposit insurance on banking stability, with a particular emphasis on the impact of deposit insurance coverage levels. Concerning economic control factors, the results of our models tell us that GDP is a preferred measure of economic conditions concerning banking sector stability of jurisdictions with deposit insurance systems. This was a result that we had seen in the literature, although some studies suggested we should have found more associations with other economic control factors, such as money supply measures and interest rates. Therefore, we recommend that generally, GDP measures are a good starting point in assessing the banking stability of jurisdictions if they have deposit insurance systems. It is, however, also important to consider a wider array of economic factors for completeness.

Furthermore, the use of different models provided important insights into affected regions due to economic factors. Comparing the two regions, Europe had fewer significant associations with economic control factors compared to Asia and we inferred that deposit insurance systems in Europe have an insulating effect on the stability of the banking sector from an economic downturn. Nonetheless, we advise policymakers to be aware of differences due to location, so European policymakers may need to examine a variety of economic factors and also be mindful of the influence that deposit insurance has on economic factors. As we saw for negative associations for certain economic factors such as GDP growth and stability measures in Asia, Asian countries' policymakers should consider this unusual relationship in their assessment of the stability of banking systems. This is because it contradicts literature that typically covers European and other advanced economies.

Another interesting finding was that our time models demonstrated that the stage of maturity of the deposit insurance systems has consequences for the associations with economic measures. We found that bank concentration was a more significant stability measure in the contemporary model, when 'too big to fail was more of a concern and likely shaped the design of contemporary deposit insurance to cope with larger failures. Hence, we recommend that policymakers link the current stage of development of their deposit insurance systems and their banking models (i.e., concentrated banking system) when assessing the influence of economic conditions and deposit insurance, with the systemic risk banking institutions will engage in. The results reinforce the need to conduct further research into the institutional environment and the relationships with deposit insurance. Anginer et al. (2014) found good regulatory and institutional frameworks, including supervision, kept in check the moral hazard arising from deposit insurance and enabled stabilization of the benefits of deposit insurance. 
Moreover, institutional strength is a key consideration for deposit insurers as robust institutions and supervision constitute an important assumption in designing an effective deposit insurance system (IADI 2014). Here, our findings will be of interest to policymakers as it shows there can be variations in the institutional environment in jurisdictions with deposit insurance and warrants more research. Throughout this study, the models have demonstrated that for jurisdictions with deposit insurance schemes in place, financial stability has significant associations with certain control factors for the economy, institutional environment, and level of deposit insurance coverage. This tells us that deposit insurance can influence financial stability and consequently, the designs of deposit insurance systems can potentially affect the banking system, for good or bad.

Regarding policymakers, we see that the differences between the holistic, regional, and time-based results reinforce the interplay of cultural factors, economic conditions, and level of maturity and variations of banking models. Consequently, government or industry officials who are considering new policies in different jurisdictions should first test the impacts of those policies using local data to ensure the suitability of new laws. Finally, the purpose of deposit insurance is to protect depositors who have put their money in the bank, expecting that it will be secure and offer a safe and low-risk return. More importantly, the behavior of the 'person on the street' plays a major part in financial crises, such as deciding when to run on a bank in a panic or when to trust the system. However, human behavior is complicated and makes it difficult to predict how each person applies their own biases, reference points, and experiences, etc. (Muradoglu 2015).

The results from this study tell us that implementing deposit insurance systems and selecting the right coverage limits requires careful assessment. Depositors should understand the rationale behind coverage levels so that it fits their respective jurisdiction. However, while a low coverage limit may statistically be the better option, a depositor may not feel reassured that his or her deposits are safe, compared to a much higher level of protection. Therefore, we recommend that policymakers spend time surveying and compiling information on the perception of deposit insurance coverage levels by depositors and factor this element of human behavior into their assessment. This is an area that we have not seen extensive work on in the current literature. The human behavioral element is a variable that is likely to be abstract; nonetheless, it is an interesting area for future research to pursue and introduce into a model to examine deposit insurance, human behavior, and financial stability.

Author Contributions: Conceptualization, N.A. and G.S.; methodology, G.S. and M.I.B.; validation, N.A., G.S. and M.I.B.; formal analysis, G.S. and M.I.B.; data curation, G.S.; writing-original draft preparation, N.A. and G.S.; writing-review and editing, N.A. and M.I.B. All authors have read and agreed to the published version of the manuscript.

Funding: This research received no external funding.

Institutional Review Board Statement: Not applicable.

Informed Consent Statement: Not applicable.

Data Availability Statement: Publicly archived datasets identified in the paper were analyzed in this study. The datasets can be accessed at https:/ / www.iadi.org/en/about-iadi/deposit-insurancesystems / dis-worldwide (accessed on 1 January 2021), World Bank at https:/ /www.worldbank.org/ en/publication/gfdr/data/financial-structure-database (accessed on 1 January 2021) and countries respective central bank.

Conflicts of Interest: The authors declare no conflict of interest. 
Appendix A. Jurisdictions with Explicit Deposit Insurance Schemes Used in This

Data Set

\begin{tabular}{|c|c|c|c|}
\hline \multicolumn{2}{|c|}{ Countries with Explicit Deposit Insurance Schemes } & \multirow{2}{*}{$\begin{array}{c}\text { Year of Establishment } \\
2002\end{array}$} & \multirow{2}{*}{$\begin{array}{l}\text { Region } \\
\text { Europe }\end{array}$} \\
\hline 1 & Albania & & \\
\hline 2 & Australia & 2008 & Asia \\
\hline 3 & Austria & 1979 & Europe \\
\hline 4 & Bangladesh & 1984 & Asia \\
\hline 5 & Belarus & 1996 & Europe \\
\hline 6 & Belgium & 1974 & Europe \\
\hline 7 & Bosnia and Herzegovina & 2002 & Europe \\
\hline 8 & Brunei Darussalam & 2011 & Asia \\
\hline 9 & Bulgaria & 1999 & Europe \\
\hline 10 & Croatia & 1997 & Europe \\
\hline 11 & Cyprus & 2000 & Europe \\
\hline 12 & Czech Republic & 1994 & Europe \\
\hline 13 & Denmark & 1987 & Europe \\
\hline 14 & Estonia & 1998 & Europe \\
\hline 15 & Finland & 1969 & Europe \\
\hline 16 & France & 1980 & Europe \\
\hline 17 & Germany & 1998 & Europe \\
\hline 18 & Greece & 1995 & Europe \\
\hline 19 & Hong Kong & 2004 & Asia \\
\hline 20 & Hungary & 1993 & Europe \\
\hline 21 & Iceland & 1985 & Europe \\
\hline 22 & India & 1961 & Asia \\
\hline 23 & Indonesia & 2004 & Asia \\
\hline 24 & Ireland & 1989 & Europe \\
\hline 25 & Italy & 1987 & Europe \\
\hline 26 & Japan & 1971 & Asia \\
\hline 27 & Korea, Rep. of & 1996 & Asia \\
\hline 28 & Kosovo & 2011 & Europe \\
\hline 29 & Laos & 1999 & Asia \\
\hline 30 & Latvia & 1998 & Europe \\
\hline 31 & Liechtenstein & 2001 & Europe \\
\hline 32 & Lithuania & 1996 & Europe \\
\hline 33 & Luxembourg & 1989 & Europe \\
\hline 34 & Macedonia & 1997 & Europe \\
\hline 35 & Malaysia & 2005 & Asia \\
\hline 36 & Malta & 2003 & Europe \\
\hline 37 & Marshall Islands & 1975 & Europe \\
\hline 38 & Moldova & 2004 & Europe \\
\hline 39 & Mongolia & 2013 & Asia \\
\hline 40 & Montenegro & 2004 & Europe \\
\hline
\end{tabular}




\begin{tabular}{cccc}
\hline Countries with Explicit Deposit Insurance Schemes & Year of Establishment & Region \\
\hline $\mathbf{4 1}$ & Nepal & 2010 & Asia \\
\hline $\mathbf{4 2}$ & Netherlands & 1978 & Europe \\
\hline $\mathbf{4 3}$ & Norway & 1961 & Europe \\
\hline $\mathbf{4 4}$ & Philippines & 1963 & Asia \\
\hline $\mathbf{4 5}$ & Poland & 1995 & Europe \\
\hline $\mathbf{4 6}$ & Portugal & 1992 & Europe \\
\hline $\mathbf{4 7}$ & Romania & 1996 & Europe \\
\hline $\mathbf{4 8}$ & Russian Federation & 2003 & Europe \\
\hline $\mathbf{4 9}$ & Serbia & 1989 & Europe \\
\hline $\mathbf{5 0}$ & Singapore & 2006 & Asia \\
\hline $\mathbf{5 1}$ & Slovak Republic & 1996 & Europe \\
\hline $\mathbf{5 2}$ & Slovenia & 2001 & Europe \\
\hline $\mathbf{5 3}$ & Spain & 1977 & Europe \\
\hline $\mathbf{5 4}$ & Sri Lanka & 2012 & Asia \\
\hline $\mathbf{5 5}$ & Sweden & 1996 & Europe \\
\hline $\mathbf{5 6}$ & Switzerland & 1984 & Europe \\
\hline $\mathbf{5 7}$ & Thailand & 2008 & Asia \\
\hline $\mathbf{5 8}$ & Turkey & 1983 & Asia \\
\hline $\mathbf{5 9}$ & Ukraine & 1998 & Europe \\
\hline $\mathbf{6 0}$ & United Kingdom & 1982 & Europe \\
\hline $\mathbf{6 1}$ & Vietnam & 2000 & Asia \\
\hline & & & \\
\hline & & & \\
\hline
\end{tabular}

\section{Note}

1 For various risks during the crises period, including the Eurozone public debt crisis at the end of 2009, readers may refer to Boubaker et al. (2016).

\section{References}

Alam, Nafis, Muhammad Ishaq Bhatti, and James, T. F. Wong. 2018. Assessing Sukuk defaults using value-at-risk techniques. Managerial Finance 44: 665-87. [CrossRef]

Al Rahahleh, Naseem, and Muhammad Ishaq Bhatti. 2017. Co-movement measure of information transmission on international equity markets. Physica A: Statistical Mechanics and Its Applications 470: 119-31. [CrossRef]

Anginer, Deniz, Asli Demirguc-Kunt, and Min Zhu. 2014. How does deposit insurance affect bank risk? Evidence from the recent crisis. Journal of Banking and Finance 48: 312-21. [CrossRef]

Ariff, Mohamed, Alireza Zarei, and Muhammad Ishaq Bhatti. 2021. Monitoring exchange rate instability in 12 selected Islamic economies. Journal of Behavioral and Experimental Finance 31: 100517. [CrossRef]

Azmat, Saad, Mohamed A. S. Sohel Azad, Muhammad Ishaq Bhatti, and Hamza Ghaffar. 2020. Islamic Banking, Costly Religiosity and Competition. Journal of Financial Research 43: 263-303. [CrossRef]

Baghdadi, Ghasan A., Muhammad Ishaq Bhatti, Lily H. G. Nguyen, and Edward J. Podolski. 2018. Skill or effort? Institutional ownership and managerial efficiency. Journal of Banking and Finance 91: 19-33. [CrossRef]

Barros, Carlos P., Candida Ferreira, and Jonathan Williams. 2007. Analysing the determinants of performance of best and worst European banks: A mixed logit approach. Journal of Banking and Finance 31: 2189-203. [CrossRef]

Barth, James R., Gerard Caprio Jr., and Ross Levine. 2004. Bank regulation and supervision: what works best? Journal of Financial Intermediation 13: 205-48. [CrossRef]

Barth, James R., Gan Jie, and Daniel E. Nolle. 2009. Global Banking Regulation and Supervision: What are the Issues and What Are the Practices? New York: Nova Science Publishers, Inc.

Beck, Thorsten, Asli Demirgüç-Kunt, and Ross Levine. 2006. Bank concentration, competition, and crises: First results. Journal of Banking and Finance 30: 1581-603. [CrossRef]

Boubaker, Sabri, Do Duc Trung, Hammami Helmi, and Kim Cuong Ly. 2020. The role of bank affiliation in bank efficiency: A fuzzy multi-objective data envelopment analysis approach. Annals of Operations Research, 1-29. [CrossRef]

Boubaker, Sabri, Buchanan Bonnie, and Duc Khuong Nguyen. 2016. Risk Management in Emerging Markets: Issues, Framework, and Modeling. Bingley: Emerald Group Publishing. 
Cerrone, Rosaria. 2018. Deposit guarantee reform in Europe: does European deposit insurance scheme increase banking stability? Journal of Economic Policy Reform 21: 224-39. [CrossRef]

Chi, Pham Thi, and Dao Thanh Binh. 2020. Deposit insurance and bank risks in Vietnam. Business and Economic Research 10: 46-63. [CrossRef]

De Graeve, Ferre, Thomas K. Kick, and Michael Koetter. 2008. Monetary Policy and Bank Distress: An Integrated Micro-Macro Approach. Frankfurt am Main: Deutsche Bundesbank.

Demirgüç-Kunt, Asli, and Enrica Detragiache. 2002. Does deposit insurance increase banking system stability? An empirical investigation. Journal of Monetary Economics 49: 1373-406. [CrossRef]

Demirgüç-Kunt, Asli, and Harry Huizinga. 2004. Market discipline and deposit insurance. Journal of Monetary Economics 51: 375-99. [CrossRef]

Demirgüç-Kunt, Asli, and Edward J. Kane. 2002. Deposit Insurance Around the Globe: Where Does It Work? Journal of Economic Perspectives 16: 175-95. [CrossRef]

Demirgüç-Kunt, Asli, Edward J. Kane, and Luc Laeven. 2008a. Determinants of deposit-insurance adoption and design. Journal of Financial Intermediation 17: 407-38. [CrossRef]

Demirgüç-Kunt, Asli, Edward J. Kane, and Luc Laeven. 2008b. Deposit Insurance Around the World: Issues of Design and Implementation. Cambridge: MIT Press.

Demirgüç-Kunt, Asli, Edward J. Kane, and Luc Laeven. 2014a. Deposit Insurance Database. International Monetary Fund (WP/14/18). Available online: http:/ /ideas.repec.org/p/imf/imfwpa/14-118.html (accessed on 1 March 2021).

Demirgüç-Kunt, Asli, Edward J. Kane, and Luc Laeven. 2014b. Deposit Insurance Database. NBER Working Paper Series, 1-43. Available online: http:/ / econpapers.repec.org/RePEc:imf:imfwpa:14/118 (accessed on 1 March 2021).

Diamond, Douglas W., and Philip H. Dybvig. 1983. Bank Runs, Deposit Insurance, and Liquidity. Journal of Political Economy 91: 401. [CrossRef]

Evanoff, Douglas Darrell, and George G. Kaufman. 2011. The International Financial Crisis: Have the Rules of Finance Changed? Singapore and Hackensack: World Scientific Pub. Co.

Flannery, Mark J. 1991. Pricing deposit insurance when the insurer measures bank risk with error. Journal of Banking and Finance 15: 975-98. [CrossRef]

Garcia, Gillian. 1999. Deposit Insurance: A Survey of Actual and Best Practices. IMF Working Paper. Washington, DC: International Monetary Fund.

Gavin, Michael, and Haussman Ricardo. 1996. The roots of banking crises: The macroeconomic context. In Banking Crises in Latin America. Edited by Ricardo Hausmann and Liliana Rojas-Suarez. Washington, DC: John Hopkins University Press, pp. $27-63$.

Grilli, Vittorio, Donato Masciandaro, and Guido Tabellini. 1991. Political and monetary institutions and public financial policies in the industrial countries. Economic Policy 6: 341-92. [CrossRef]

Gropp, Reint, and Jukka Vesala. 2004. Deposit insurance, moral hazard and market monitoring. Journal of Finance 8: 571-602.

Hutchison, Michael M. 2002. European Banking Distress and EMU: Institutional and Macroeconomic Risks. Scandinavian Journal of Economics 104: 365-89. [CrossRef]

IADI. 2014. Core Principles for Effective Deposit Insurance Systems. International Association of Deposit Insurers. Available online: http:/ / www.iadi.org/en/assets/File/CorePrinciples/cprevised2014nov.pdf (accessed on 1 March 2021).

IADI. 2021. International Association of Deposit Insurers (IADI). Deposit Insurance Systems Worldwide. Available online: https: //www.iadi.org/en/about-iadi/deposit-insurance-systems/dis-worldwide/ (accessed on 1 March 2021).

Igwe, Elizabeth I., and Adolphus J. Toby. 2021. Deposit insurance and credit risk of Nigeria banking system: a time series analysis. Journal of Global Economics and Business 2: 1-30.

Ingves, Governor Stefan. 2012. Financial stability is important for us all. Speech to Riksdag Committee on Finance. pp. 1-10. Available online: http:/ / archive.riksbank.se/en/Web-archive/Published/Speeches/2012/Ingves-Financial-stability-is-important-forus-all/index.html (accessed on 1 March 2021).

Jokipii, Terhi, and Pierre Monnin. 2013. The impact of banking sector stability on the real economy. Journal of International Money and Finance 32: 1-16. [CrossRef]

Kam Hon, Chu. 2011. Deposit insurance and banking stability. CATO Journal 31: 99-117.

Kozińska, Magdalena. 2021. Role of deposit insurance schemes on financial markets. International Journal of Monetary Economics and Finance 14: 91-104. [CrossRef]

Lé, Mathias. 2013. Deposit Insurance Adoption and Bank Risk-Taking: The Role of Leverage. Débats Économiques Et Financiers 9. Paris: Banque de France.

Lu, Ying Fang, Christopher Gan, Baiding Hu, Moau Y. Toh, and David A. Cohen. 2018. Bank efficiency in New Zealand: a stochastic frontier approach. New Zealand Economic Papers 53: 1-18. [CrossRef]

Morrison, Alan D., and Lucy White. 2011. Deposit insurance and subsidized recapitalizations. Journal of Banking and Finance 35: 3400-16. [CrossRef]

Muradoglu, G. 2015. Human Psyche, Financial Panic and Bank Runs. Paper preasent at International Association of Deposit Insurers 14th Annual Conference, Kuala Lumpur, Malaysia, June 8.

Ngo, Thanh, and Tu Le. 2019. Capital market development and bank efficiency: A cross-country analysis. International Journal of Managerial Finance 15: 478-91. [CrossRef] 
Nguyen, Cuong, Muhammad Ishaq Bhatti, Magda Komorníková, and Jozef Komorník. 2016. Gold price and stock markets nexus under mixed-copulas. Economic Modelling 58: 283-92. [CrossRef]

Nguyen, Tram, David Tripe, and Thanh Ngo. 2018. Operational Efficiency of Bank Loans and Deposits: A Case Study of Vietnamese Banking System. International Journal of Financial Studies 6: 14. [CrossRef]

Nizar, Muhammad A., and Alfan Mansur. 2021. Can the Indonesian banking industry benefit from a risk-based deposit insurance system? Macroeconomics and Finance in Emerging Market Economies, 1-20. [CrossRef]

Rastogi, Shailesh, Rajani Gupte, and R. Meenakshi. 2021. A Holistic Perspective on Bank Performance Using Regulation, Profitability, and Risk-Taking with a View on Ownership Concentration. Journal of Risk and Financial Management 14: 111. [CrossRef]

Sabourin, Jean Pierre. 2020. Rethinking the Role of Deposit Insurance: Lessons from the Recent Financial Crisis. In Financial Crisis Management and Bank Resolution. Edited by John Raymond Labrosse. Informa Law from Routledge. Abingdon: Routledge, pp. 133-38.

Samet, Anis, Narjess Boubakri, and Sabri Boubaker. 2018. Does public-private status affect bank risk taking? Worldwide evidence. Journal of International Financial Markets, Institutions and Money 53: 287-306. [CrossRef]

Schaeck, Klaus, Martin Cihak, and Simon Wolfe. 2009. Are competitive banking systems more stable? Journal of Money, Credit and Banking 41: 711-34. [CrossRef]

Stark, Jürgen. 2009. Monetary Policy before, during and after the financial crisis Speech by Jürgen Stark, Member of the Executive Board. In Speech by Jürgen Stark, Member of the Executive Board of the ECB, University Tübingen, Tübingen, 9 November 2009. Tübingen: Baden-Württemberg, pp. 1-12.

Wiedner, Klaus. 2020. A Common European Deposit Insurance System on the Path Towards a Steady-State Banking Union. In EDIS, NPLs, Sovereign Debt and Safe Assets. Berlin: De Gruyter, pp. 39-58.

World Bank. 2014a. Financial Development and Structure Dataset. Washington, DC: The World Bank.

World Bank. 2014b. World Governance Indicators. Available online: www.govindicators.org (accessed on 1 March 2021). 